\title{
Optimization of long-term graft survival after liver transplantation: the role of donor age
}

\author{
Q Lai", F Melandro, G Spoletini, GB Levi Sandri, N Guglielmo, S Ginanni Corradini, PB Berloco, M Rossi \\ From XXIII Annual Meeting of the Italian Society of Geriatric Surgery \\ Lecce, Italy. 2-4 December 2010
}

\section{Background}

Nowadays, several solutions have been proposed for the minimization of both organ shortage and prolonged waiting times: the expansion of the donor pool using aged donors represents a possible solution [1]. However, it is not completely clear if the use of "extreme" donors could cause unacceptable post-transplant adjunctive risks [2]. Starting from these grounds, the aim of this study is to evaluate the impact of donor age on longterm graft survival.

\section{Materials and methods}

From January 2001 to April 2009, 188 consecutive liver transplantations were performed at our Department. The entire cohort was stratified in 4 subgroups according to donor age: Group $1\left(1^{\text {st }}-2^{\text {nd }}\right.$ decade, $\left.n=34\right)$, Group $2\left(3^{\text {rd }}-4^{\text {th }}\right.$ decade, $\left.\mathrm{n}=51\right)$, Group $3\left(5^{\text {th }}-6^{\text {th }}\right.$ decade, $\left.\mathrm{n}=75\right)$ and Group $4\left(7^{\text {th }}-8^{\text {th }}\right.$ decade, $\left.\mathrm{n}=28\right)$. Donor, recipient and transplantation characteristics were compared in the 4 groups. ANOVA test and Kruskal-Wallis test were used for the comparison of continuous and categorical variables. Kaplan-Meier test was adopted for survival analysis: log-rank test was used for comparison among the groups' survival rates.

\section{Results}

As expected, donor age, percentage of cerebrovascular deaths, BMI and DRI resulted higher in the last group. The male gender was prevalent in the $1^{\text {st }}$ Group, while macrovescicular steatosis resulted higher in the $3^{\text {rd }}$ Group. Recipient and immediate post-transplant features resulted homogeneous among the groups. At survival analysis, 5-year graft survival rates were progressively

\footnotetext{
* Correspondence: lai.quirino@libero.it Department of General Surgery and Organ Transplantation, Sapienza University, Rome, Italy
}

worsened among the groups (82.4 vs 73.3 vs 64.7 vs $39.6 \%$, respectively). At log-rank analysis, statistical significance was observed between the first 2 Groups and $4^{\text {th }}$ one ( $p$-value 0.003 and 0.006 , respectively), while a boundary statistical significance was observed between the $1^{\text {st }}$ and $3^{\text {rd }}$ Group. Figure 1.

\section{Conclusions}

In our experience, use of $<70$ year-aged donors seems to be safe, while very aged (over 70) donors give poor long-term survival rates, despite similar initial posttransplantation results. We could speculate that grafts procured by very aged donors could be easier targets of viral recurrence, late ischemia-reperfusion damage and chronic rejection. A better allocation system for these organs may be improved, preferring $\mathrm{HCC}$ recipients who exceed transplant criteria to HCV ones [3].

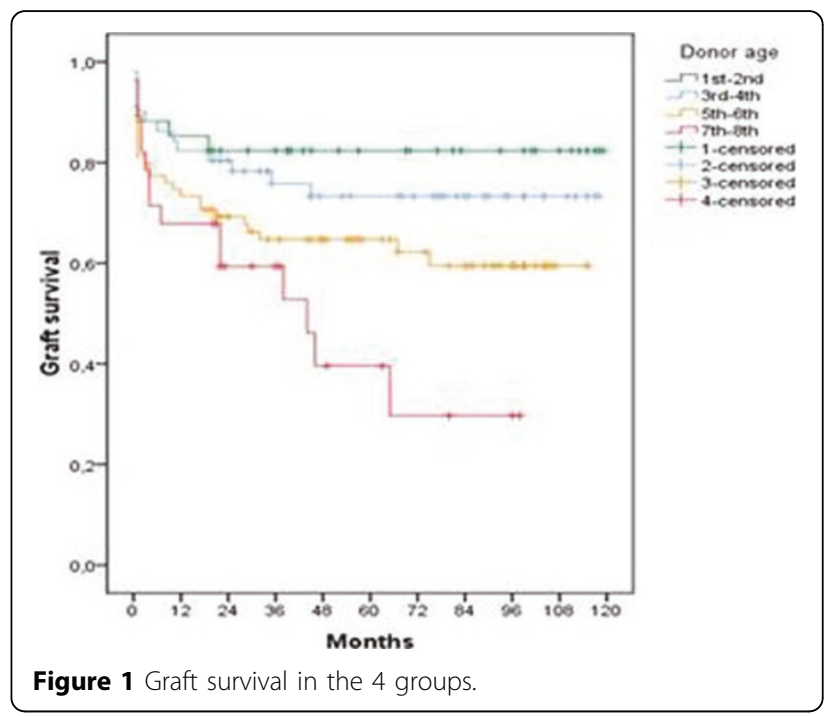




\section{References}

1. Pirenne J, Monbaliu D, Van Gelder F, Van Hees D, Aerts R, Verslype C, et al: Liver transplantation using livers from septuagenarian and octogenarian donors: an underused strategy to reduce mortality on the waiting list. Transplant Proc 2005, 37:1180-1.

2. Tector AJ, Mangus RS, Chestovich P, Vianna R, Fridell JA, Milgrom ML, et al: Use of extended criteria livers decreases wait time for liver transplantation without adversely impacting posttransplant survival. Ann Surg 2006, 244:439-50.

3. Sotiropoulos GC, Paul A, Molmenti E, Lang H, Frilling A, Napieralski BP, et al: Liver transplantation for hepatocellular carcinoma in cirrhosis within the Eurotransplant area: an additional option with "livers that nobody wants". Transp/ 2005, 80:897-902.

doi:10.1186/1471-2318-11-S1-A25

Cite this article as: Lai et al:: Optimization of long-term graft survival after liver transplantation: the role of donor age. BMC Geriatrics 201111 (Suppl 1):A25.

\section{Submit your next manuscript to BioMed Central} and take full advantage of:

- Convenient online submission

- Thorough peer review

- No space constraints or color figure charges

- Immediate publication on acceptance

- Inclusion in PubMed, CAS, Scopus and Google Scholar

- Research which is freely available for redistribution

Submit your manuscript at www.biomedcentral.com/submit
Ciomed Central 